Egyptian J. Anim. Prod. (1999) 36 (2):83-91

\title{
EFFECT OF HEAT DETECTION REGIME ON THE COST OF DAYS OPEN AND LONGEVITY OF BUFFALOES
}

\author{
A.H. Barkawi ${ }^{1}$, A. M. Ahmed ${ }^{2}$,M. A. El-Wardani ${ }^{3}$,Amal K. El-Asheeri ${ }^{1}$ \\ and M.K. Hamed ${ }^{1}$ \\ 1- Animal Production Department, Faculty of Agriculture, Cairo University, Giza, \\ Egypt, 2- Desert Research Center, Mataria, Egypt, 3-Animal Production Research \\ Institute, Ministry of Agriculture, Giza, Egypt.
}

\section{SUMMARY}

Fifty-nine milking buffaloes belonging to the Mehalet Mousa Research Station, Animal Production Research Institute, Ministry of Agriculture, Egypt, were used in this study to estimate post-partum technical coefficients from parturition to conception. To study the impact of frequency of heat detection on the cost of days open, animals were divided into two groups. Estrus was checked twice daily in the first group (G1) and four times in the second group (G2). Days from calving to conception were recorded as well as the number of services / conception. Costs of hired labor, feeding, veterinary service, and insemination were calculated according to the current prices and were summed up to estimate the total cost of the days open period. An empirical study based on the post-partum technical coefficients drawn from the experimental part and the data of the farm were used to compare between the two systems.

Number of animals conceived throughout the first 120 days post-partum was higher in $\mathrm{G} 2$ than $\mathrm{G} 1$. This, consequently, shortened $(P<0.05)$ days open of $\mathrm{G} 2$ by $25 \%$ than in G1. Accordingly, cost of days open in G2 was 8\% less (LE 291.8). Cost of days open of $\mathrm{G} 2$ throughout the periods $<60,61-120$ and $>120$ days post-partum were less than in G1 by $10.2,14.5$ and $8 \%$, respectively. Daily cost of days open increased significantly $(P<0.01)$ with the increase of days open up to 120 days. Thereafter, cost went down.

Under G2 regime of heat detection, any buffalo is expected to deliver 9.3 lactations during her lifetime production vs. 8.8 for $\mathrm{G} 1$, resulting in 0.5 more lactations. At herd level $(\mathrm{n}=30)$, cows under this regime could gain 14.4 tons more milk in addition to 11 more weaned calves. Moreover, this regime is expected to reduce the cost of days open by an amount of LE 8,759 for the herd.

Keywords: Buffaloes, days open, cost, lifetime production

Issued by The Egyptian Society of Animal Production 


\section{INTRODUCTION}

Increasing farm profitability is the main goal of dairy herdsman. Beside milk income, both regularity of calving and the length of calving interval influence profit of dairy farms, which affects the overall productive life of dairy animals.

Most of the previous studies on Egyptian buffaloes reported long calving intervals (> 450 days, El-Shiekh, 1967 and Metry et al., 1994). Such long intervals were estimated under the common practice of heat detection in the state and experimental farms (twice daily). Observing estrus twice a day (between 0600 $1400 \mathrm{~h}$ ) causes misdetection of many heat periods and increases the frequency of the recorded quiet ovulation cases (50-60\%, Barkawi et al., 1986 and Aboul Ela et al., 1987) which has a negative impact on the farm profitability.

Many research workers tried to shorten days open length, the main determinant of calving interval, by either hormonal manipulation (Barkawi and Aboul-Ela, 1989) or increasing the frequency of heat detection (Barkawi et al., 1998). Although, these two methods could shorten significantly the calving interval, they may increase the labor cost and decrease the farm net revenues (Federico et al., 1987).

The present work aims at evaluating the impact of the frequency of heat detection on the total cost of days open and to estimate its affects on buffalo's life production.

\section{MATERIALS AND METHODS}

\section{1- Experimental animals and management}

The trial was conducted on 59 milking buffalves between the $2^{\text {nd }}$ and $8^{\text {th }}$ parities belonging to the Mehalet Mousa Research Station, Animal Production Research Institute, Ministry of Agriculture, Egypt. Animals calved normally and were diagnosed as free of reproductive diseases at the beginning of the trial. Animals were housed loose in semi-shed open yards and were allowed to nurse their calves for seven days. Thereafter, animals were hand-milked twice daily at $0700 \mathrm{~h}$ and $1400 \mathrm{~h}$ during the experimental period (extended from calving to conception). Buffaloes were fed individually according to their body weight $(X=474 \pm 84 \mathrm{~kg})$ and milk production level $(X=6.5 \pm 0.2 \mathrm{~kg} /$ day $)$. The average daily ration per head was $2 \mathrm{~kg}$ of concentrate mixture, $40 \mathrm{~kg}$ of green fodder (Trifolium alexandrinum) and $5 \mathrm{~kg}$ of rice straw during the cold season (November- April). Green fodder was replaced by 5 $\mathrm{kg} /$ day of Trifolium alexandrinum hay during the hot season (May-October).

\section{2- Experimental procedure}

Animals were divided into two groups, with no significant difference in means of parity, body weights and milk production during the first 100 days. In the first group (G1), estrus was checked twice daily at $0800 \mathrm{~h}$ and $1500 \mathrm{~h}$. In the second group (G2) buffaloes were checked four times, at six-hour intervals starting at $0600 \mathrm{~h}$. In each estrous detection round (time), buffaloes were observed in the presence of a teaser

bull for 30 minutes to identify females in heat. Buffaloes were mated naturally as early as they showed the first estrus post-partum. Days open (DO) defined as days 
from calving to conception, was recorded as well as the number of services/conception (NS/C). The obtained averages of the above mentioned reproductive criteria were used as the technical coefficients for each of the studied groups.

\section{3- Data}

To estimate the total cost during the days open period, the costs of the following items were considered in terms of the current prices in Egyptian pounds (LE).

I ) Hired labor (permanent, and part time workers for milking and feeding)

ii) Feeding (roughage and green fodder and concentrate feed mixture)

iii) Veterinary service, supplies and drugs

iv) Heat detection (rate of laber wage of $\mathrm{G} 2$ is double of $\mathrm{G} 1$ )

v) Insemination and palpation

An empirical study based on the technical coefficients drawn from the experimental part and the prevailing technical coefficients available in the farm were used to compare the two studied systems.

To study the impact of the frequency of heat detection on the profitability of the farm during the expected life time production of the buffaloes in the herd, the following coefficients were assumed for the two herds (groups) under investigation:

- Herd size (number of breeding buffaloes) per group $=30$ heads (representing the average of large buffalo herds)

- Age at first calving for both groups $=36$ months

- Age at culling for buffaloes in both groups $=144$ months

- Total milk yield per buffalo $=1200 \mathrm{~kg}$

- Conception rate $=80 \%$

- Calving interval $=$ obtained $\mathrm{DO}+315$ days $($ average of gestation period)

- Mortality rate of new born calves up to weaning $=10 \%$

- The price of the inputs will be unchanged during the study.

- Cost of management during pregnancy was assumed to be equal in both groups.

- All other technical coefficients were kept constant.

\section{4- Statistical Analysis}

Data were analyzed by least squares technique using the general linear model of SAS (1990). Days open were classified into three classes, $<60$ days $(\mathrm{C} 1), 61-120$ days (C2) and $>120$ days (C3) to calculate the cost of days open for each class. The following model was assumed to underlay the least squares analysis of variance:

$$
\begin{aligned}
Y_{i j k}=U & +a_{i}+c_{j}+\left(a c_{i j}\right)+\left(b x_{i j}\right)+e_{i j k} \\
Y_{i j k} & =\text { the ijk } k^{t h} \text { observation (cost, days open, number of services / conception) } \\
\mu & =\text { the general mean, common element to all observations in the population, } \\
a_{i} & =\text { the effect due to } i^{\text {th }} \text { frequency of heat detection, } \mathrm{i}=1,2 \\
c_{j} & =\text { the effect due to } j^{\text {th }} \text { length of days open classes, } \mathrm{j}=1,2,3
\end{aligned}
$$


86

Barkawi et al.

$(\mathrm{ac})_{\mathrm{ij}}=$ the interaction between $\mathrm{i}^{\text {th }}$ frequency of heat detection and $\mathrm{j}^{\text {th }}$ length of days open classes,

b = the partial regression coefficient of $(y)$ on costs of days open intervals,

$\mathrm{x}_{\mathrm{ij}}=$ the deviation of days open, expressed in days from their respective mean,

$\mathrm{e}_{\mathrm{ijk}}=\mathrm{a}$ random $\mathrm{effect}$ associated with individual observation.

\section{5- Criteria for Comparison}

The expected number of lactation (NL), total milk yield (TMY), total reduction in the cost of days open per herd (TRE) and calf crop (CC) were estimated for each of the two studied groups. The estimates were used as criteria for comparing the effect of heat detection frequency on the overall profitability of the herd. These criteria were calculated according to the following equations:

$\mathrm{NL}=[$ (age at culling -age at first calving) $\div$ average of the calving intervals $]+1$

TMY $=$ herd size $\mathrm{x}$ difference in average number of lactation in the herd $\mathrm{x}$ average milk yield $\mathrm{x}$ conception rate $T R E=$ (total cost per cow in G1 $x$ herd size $x$ number of lactation) -

(total cost per cow in $\mathrm{G} 2 \mathrm{x}$ herd size $\mathrm{x}$ number of lactation)

$\mathrm{CC}=$ herd size $\mathrm{x}$ difference in lactation between two groups $\mathrm{x}$ conception rate $\mathrm{x}$ calf mortality rate up to weaning.

\section{RESULTS and DISCUSSION}

Effect of heat detection regime on the cost of days open

Number of animals conceived throughout the first 120 days post-partum $(\mathrm{C} 1+\mathrm{C} 2)$ was higher in buffaloes more frequently observed for estrus (G2) than those checked less frequently (G1) (Figure 1). This shortened the days open length of G2 compared to $\mathrm{Gl}$ by about $25 \%$ (about 108 vs. 80 days, Table 1), and consequently reduced the cost of days open of G2 by LE 37.9 per buffalo representing $8 \%$ of the cost reduction. Fertility of buffaloes had no significant impact on the days open, since NS/C were almost similar in the two studied groups (Table 1).

Table 1. Least squares means and their corresponding standard errors of number of services per conception (NS/C), days open and total cost in Egyptian pounds (LE) throughout the days open period for buffaloes checked twice daily (G1) or four times daily (G2) for heat detection

\begin{tabular}{ccccc}
\hline Group & No & NS/C & Days open & $\begin{array}{c}\text { Total cost } \\
\text { (LE) }\end{array}$ \\
\hline G1 & 30 & $1.5 \pm 0.1$ & $107.9 \pm 11.5$ & $525.9 \pm 22.99$ \\
G2 & 29 & $1.5 \pm 0.1$ & $80.1 \pm 11.7$ & $488.0 \pm 24.24$ \\
Overall Mean & 59 & $1.5 \pm 0.1$ & $94.2 \pm 8.2$ & $469.5 \pm 15.95$ \\
\hline
\end{tabular}




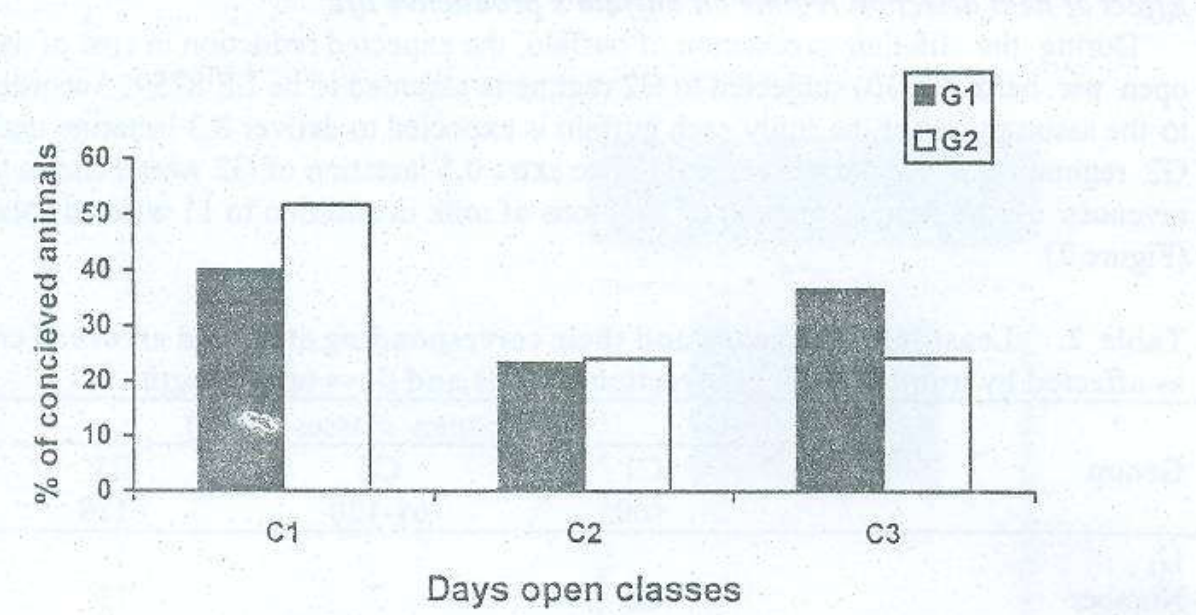

Figure 1. Percentage of conceived buffaloes under days open classes $(\mathrm{C} 1=<60$, $C 2=61-120$ and $C 3>120$ days).

The obtained shorter calving interval of G2 as compared to $\mathrm{G} 1$ is attributed to the detection of a higher number of es.ious cases, particularly those which occurred during the period from the afternoon to the morning of the next day. This agrees with the findings of Barkawi et al. (1:97) and El-Wardani and El-Asheeri (1999) who report $d$ that most of estrous cases occurred around the times of sunset and sunrise which are missed in G1 regime.

The overall data indicated that prolongation of days open resulted in an increase of the cost of the herd. Cost of days open increased gradually $(\mathrm{P}<0.01)$ with the increase of days open (Table 2). The percentage of the cost of $\mathrm{C} 2$ and $\mathrm{C} 3$ compared to $\mathrm{C} 1$ was 180.8 and $383.8 \%$, respectively.

Cost per day of days open gradually increased $(\mathrm{P}<0.01)$ during $\mathrm{C} 1$ and $\mathrm{C} 2$, while it became less in $\mathrm{C} 3$ (Table 2). Regression of cost on $\mathrm{DO}$ indicated that cost per day for $\mathrm{C} 2$ and $\mathrm{C} 3$ relative to $\mathrm{C} 1$ ( $\mathrm{LE} 4.64$ ) were +3.02 and $-1.72 \%$, respectively. This most probably is attributed to the fact that $73 \%$ of buffaloes of G2 had conceived throughout the first 120 days post-partum vs. $59 \%$ of G1 (Figure 1). The unexpected high cost during $\mathrm{Cl}$ is due either to the high wage rate of heat detection in $\mathrm{G} 2$ or to the period that coincides with the pcak of milk production where the cost of feeding is relatively higher than that of $\mathrm{C} 3$.

Cost of G2 under any class of days open was less than G1 by $10.2,14.5$ and $8 \%$ for $\mathrm{C} 1, \mathrm{C} 2$ and $\mathrm{C} 3$, respectively. Rate of increase in the cost of buffaloes conceived throughout $\mathrm{C} 2$ and $\mathrm{C} 3$ compared to $\mathrm{C} 1$ for each of $\mathrm{G} 1$ and $\mathrm{G} 2$ was 188.7 vs. $196.1 \%$ and 340 vs. $317.3 \%$, respectively. The low rate of increase in cost of G2 compared to G1 under any class of days open is attributed mainly to it's shorter days open (Table 2). 


\section{Effect of heat detection regime on buffalo's productive life}

During the lifetime production of buffalo, the expected reduction in cost of days open per herd $(n=30)$ subjected to $G 2$ regime is assumed to be LE 8759. According to the assumptions of the study each buffalo is expected to deliver 8.3 lactation under $\mathrm{G} 2$ regime, and 7.8 lactation in G1. The extra 0.5 lactation of $\mathrm{G} 2$ would add to the revenues of the farm an amount of 14.4 tons of milk in addition to 11 weaned calves (Figure 2).

Table 2. Least squares means and their corresponding standard errors of cost as affected by number of heat detection rounds and days open length.

\begin{tabular}{lccc}
\hline & \multicolumn{3}{c}{ Days open classes (days) } \\
\cline { 2 - 4 } Group & $\mathrm{C} 1$ & $\mathrm{C} 2$ & $\mathrm{C} 3$ \\
& $<60$ & $61-120$ & $>120$ \\
\hline $\mathrm{G}_{1}$ & 12 & 7 & 11 \\
Number & $46.9 \pm 1.9$ & $87.0 \pm 6.3$ & $187.0 \pm 10.7$ \\
Average of DO & $221.2 \pm 35.4$ & $433.7 \pm 46.3$ & $923.0 \pm 36.9$ \\
Cost / buffalo & & & \\
$\mathrm{G}_{2}$ & 15 & 7 & 7 \\
Number. & $40.7 \pm 2.4$ & $76.1 \pm 7.0$ & $168.4 \pm 16.2$ \\
Average of DO & $200.8 \pm 31.6$ & $378.9 \pm 46.3$ & $884.4 \pm 46.3$ \\
Cost / buffalo & & & \\
Overall mean & 27 & 14 & 18 \\
Number & $43.5 \pm 1.7$ & $81.6 \pm 4.8$ & $180.2 \pm 9.1$ \\
Average of DO & $210.9 \pm 23.7$ & $406.3 \pm 32.7$ & $903.7 \pm 29.6$ \\
Total cost / buffalo & $4.64 \pm 0.37$ & $4.78 \pm 0.63$ & $4.56 \pm 0.443$ \\
Cost / day / buffalo (LE) & & &
\end{tabular}

In conclusion, these results indicate that: a) the long days open of buffaloes are not due to their low conception rate; b) the routinely applied heat detection regime ( 2 times daily) is not sufficient to detect all the estrous cases and c) increasing frequency of heat detection would have a positive impact on the farm profitability and productive life of buffalo cows. 
Egyptian J. Anim. Prod. (1999)

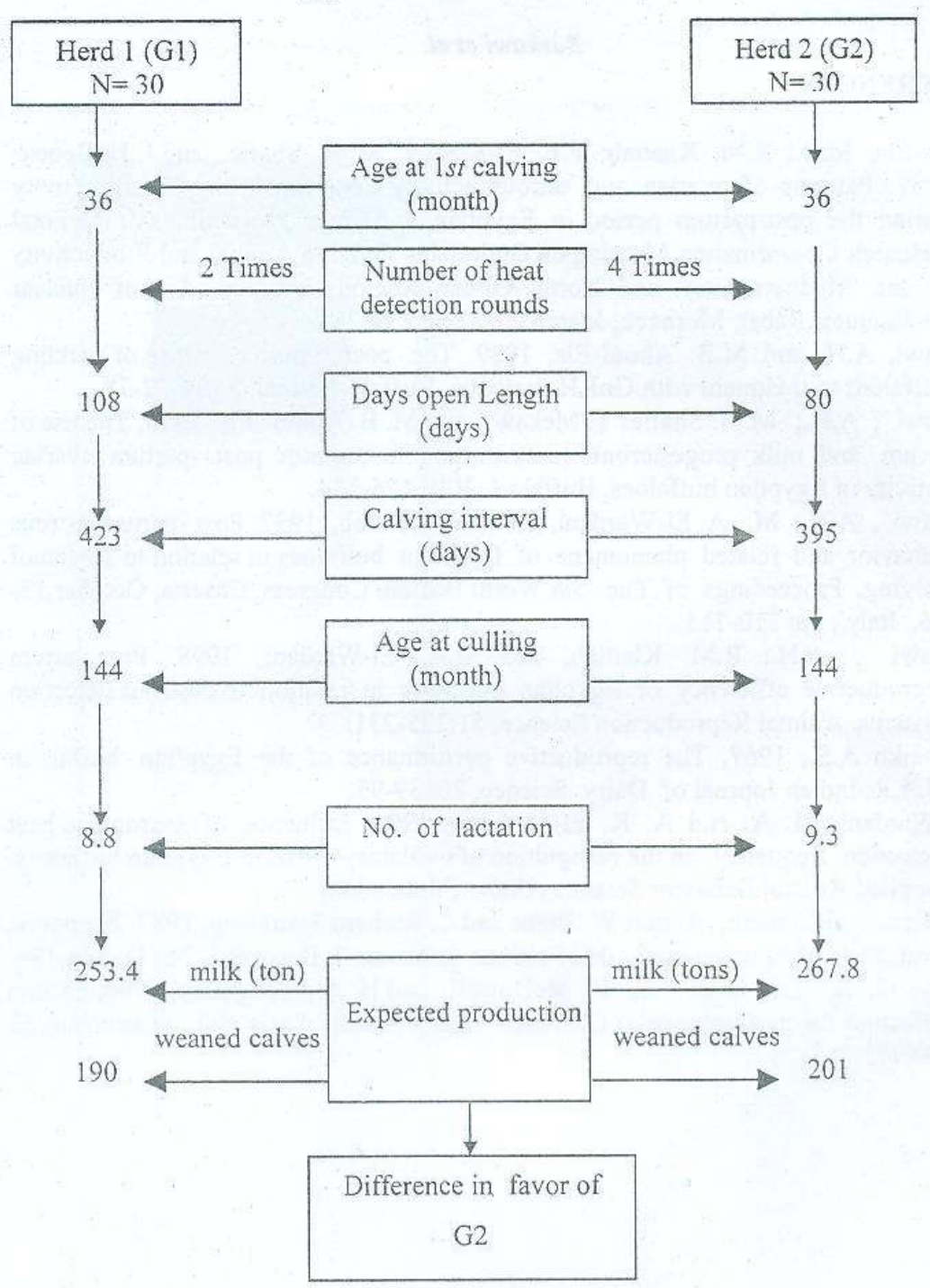

Figure 2. Expected milk production and weaned calves of two herds of buffaloes detected for heat two times daily (G1), and four times daily (G2). 


\section{REFERENCES}

Aboul-Ela, M.B.; R.M. Khattab; F.E. El-Keraby; M.M. Shafie, and L.H. Bedeir, 1987. Patterns of ovarian and estrous activity and induction of cyclic activity during the post-partum period in Egyptian buffaloes. Proceedings of the Final Research Co-ordination Meeting on Optimizing Grazing Animal and Productivity in the Mediterranean and North African Regions with the Aid of Nuclear Techniques, Rabat, Morocco, March 23-27,pp.239-254.

Barkawi, A.H. and M.B. Aboul-Ela, 1989. The post-partum response of suckling buffaloes to treatment with GnRH analogue. Buffalo Journal, 5 (2): 72-78.

Barkawi , A.H.; M.M. Shafie; Y. Mekawy, and M. B. Aboul-Ela, 1986. The use of serum and milk progesterone concentration to monitor post -partum ovarian activity in Egyptian buffaloes. Buffalo J.,2(2): 125-134.

Barkawi , A.H.; M. A. El-Wardani, and R.M. Khattab, 1997. Post -partum estrous behavior and related phenomena of Egyptian buffaloes in relation to season of calving. Proceedings of The $5 t h$ World Buffalo Congress. Caserta, October,1316, Italy, pp: 710-715.

Barkawi , A.H.; R.M. Khattab, and M.A. El-Wardani, 1998. Post-partum reproductive efficiency of Egyptian buffaloes in relation to oestrous detection systems. Animal Reproduction Science, 51:225-231.

El-Sheikh A.S., 1967. The reproductive performance of the Egyptian buffalo in U.A.R. Indian Journal of Dairy Science, 20: 89-95.

E1- Wardani, M. A. aid A. K. El- Asheeri, 1999. Influence of season and heat detection frequency on the recognition of ovulatory estrus in Egyptian buffaloes. Applied Animal Behavior Science (Under Publication)

Federico, J. Holmann, Robert W. Blake and C. Richard Shumway, 1987. Economic evaluation of fourteen methods of estrous detection. J. Dairy Sci. 70 (1): 186-194.

Metry, G. H.; J.C. Wilk, R. E. McDowell, and H. A. El-Rigalaty, 1994. Factors affecting the performance of Egyptian buffalo. Annals Agric. Sci., Moshtohor, 32 (2): $775-785$. 


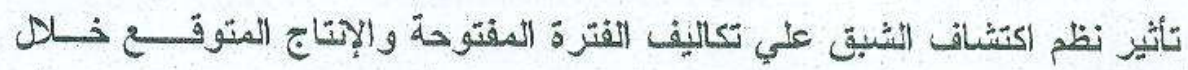
المباة الإنتاجية للباموس

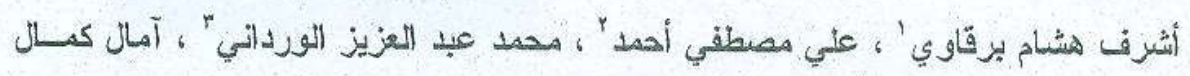

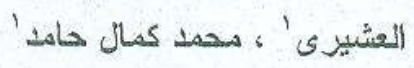

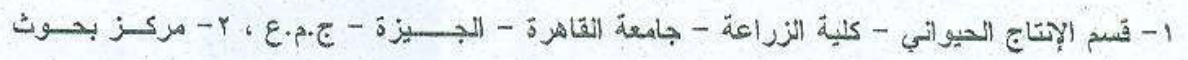

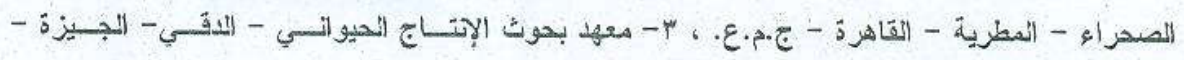
ש.

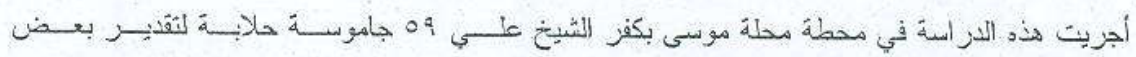

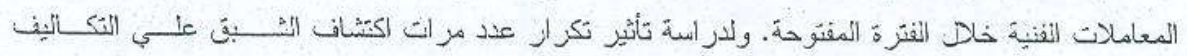

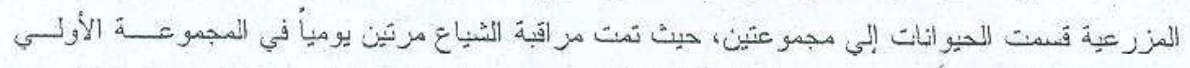

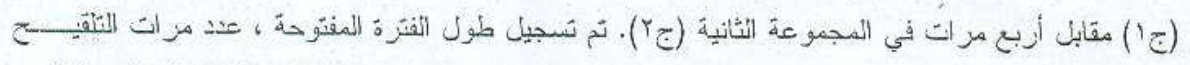

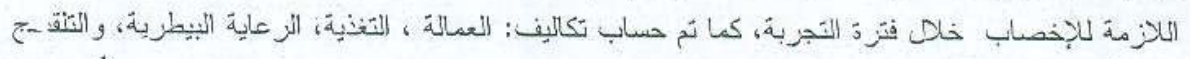

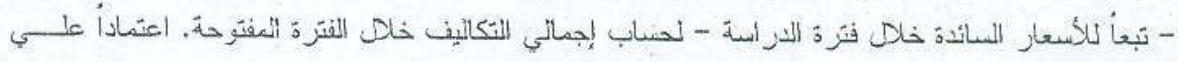

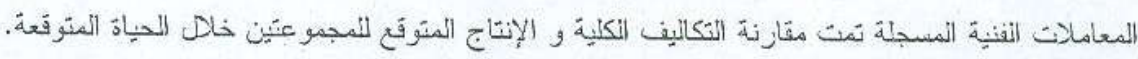

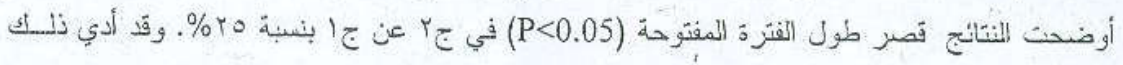

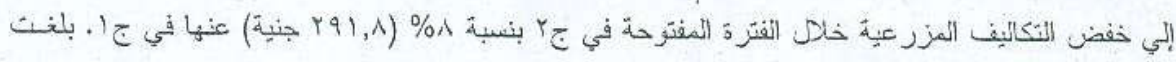

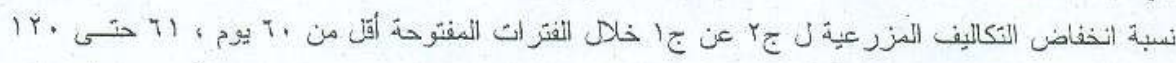

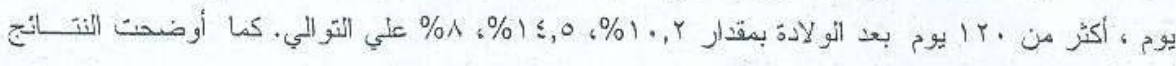

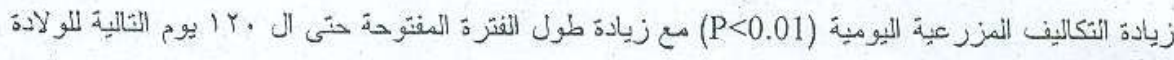

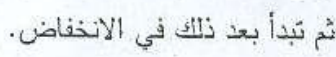

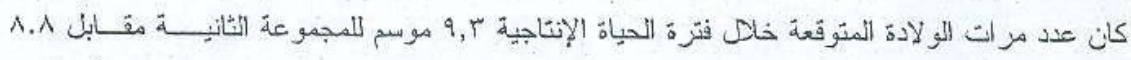

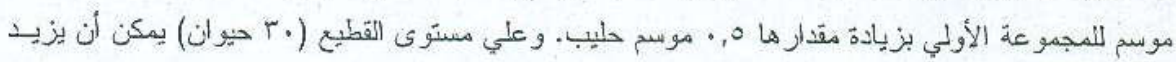

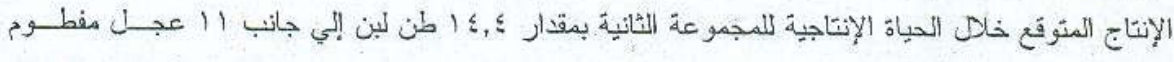

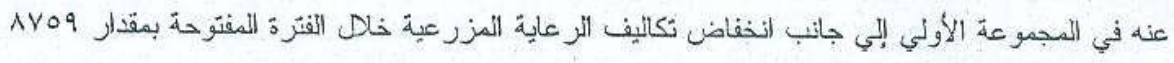

